\title{
ANALYSIS AND EVALUATION OF THE SUSTAINABLE PROTECTION AND CONTROLLED USAGE ENVIRONMENTS WITH THE SUPPORT OF GIS USING T-TEST: CASE STUDY OF ÇESME, IZMIR, TURKEY
}

\author{
Şule Birim ${ }^{1 *}$, Funda Ankaya ${ }^{2}$ \\ I*Manisa Celal Bayar University, Salihli Faculty of Economical and Administrative Sciences, Turkey; \\ ${ }^{2}$ Manisa Celal Bayar University, Alaşehir Vocational School, Alasehir, Manisa, Turkey; \\ *Corresponding Author Sule BIRIM, e-mail: sule.ozturk@ cbu.edu.tr; fundaunalankaya@ hotmail.com; \\ ORCID Authors: https://orcid.org/0000-0001-7544-8588; https://orcid.org/0000-0002-8305-1131;
}

Received June 2020; Accepted July 2020; Published August 2020;

DOI: https://doi.org/10.31407/ijees10.317

\begin{abstract}
Turkey is not only prosperous with a unique natural heritage but the cultural heritage of history of mankind and civilization. In Turkey, there are hundreds of thousands of hectares of natural protected environments with boundaries. Loss of site characteristics and dissolution caused by boundary restriction and change of status are particularly vital problems facing the hundreds of thousands of hectares naturally protected environments conserved by laws in Turkey. In the country, natural protected area is divided into three categories; 1) Sensitive area to be strictly protected, 2) Qualified natural protection areas 3) Sustainable protection and controlled usage areas. This study examines the evaluation of the Sustainable Protection and Controlled Usage Environments in Çeşme (İzmir / Turkey) district to determine the protection strategy and accurate determination based on scientific data. Based on this strategy, in Çeşme, İzmir, Turkey, 17 polygons which were specified as Sustainable Protection and Controlled Usage Areas (SPCUA) by GIS method are reevaluated by 3 specialists who were asked to answer the questions using "yes", "no", or "partly" in the chart. "yes" is given 2 points, "no" is given 0 points and "partly" is given 1 point. The goal of this paper is to examine whether there is a substantial difference between the groups specified by GIS method Using dependent sample T-Test. The result of the analysis showed there is no significant difference between the GIS method and the evaluations of all the specialists.
\end{abstract}

Keywords: Çeşme, natural protected areas, Sustainable Protection and Controlled Usage Areas, T-Test 